\title{
Mucinous carcinoma of the skin
}

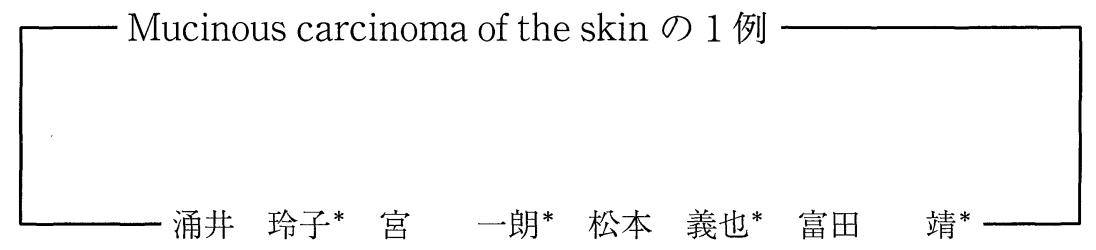

\section{Summary}

Mucinous carcinoma of the skin is a rare sweat-gland neoplasm with a tendency to recur, but metastases to regional lymph nodes and widespread metastases are uncommon. We experienced a case of mucinous carcinoma of the skin in the axilla with metastases to the axillary lymph nodes. A 69-year-old man had a 2-year history of a slowly growing papule on the left axilla. Physical examination revealed a dark purple-red, elastic hard, dome-shaped tumor with $7.5 \times 6 \times 1.5 \mathrm{~cm}$, on the left axilla. The tumor with left axillary lymph nodes were totally excised. Histopathology revealed small islands of tumor cells floating in large pools of mucin, separated by thin fibrovascular septa. The patient had no recurrence after 1 year, however, CT scan revealed several small lesions in the lungs considered as metastases of mucinous carcinoma.

Key words : Mucinous carcinoma of the skin, Lymph node metastases, Lung metastases

\section{はじめに}

mucinous carcinoma of the skin は比較的稀な 汗腺由来の腫瘍で，局所再発率は高いが，転移 例は少なく，比較的予後良好といわれている。 今回我々は，リンパ節転移をきたし，肺転移が 疑われた mucinous carcinoma of the skin の1例 を経験したので報告する。

* Reiko WAKUI, Ichirou MIYA, Yoshinari MATSUMOTO, Yasushi TOMITA : 名古屋大学皮膚科学教 室

\section{症例}

患 者: 69 歳, 男性

初 診: 平成 9 年 5 月 16 日

主 訴: 左腋窩の腫瘤

既往歴: 高血圧, 高脂血症

家族歴：特記すべきことなし。

現病歴: 平成 7 年頃より左腋窩の丘疹に気付 いていたが，自覚症状がないため放置してい た。丘疹は徐々に増大し, 平成 9 年 3 月頃には 鳿卵大となり，擦れて痛みを感じるようになっ たため，近病院皮膚科を受診。生検にて腺癌の 皮膚転移が疑われ，全身検索が行われたが原発 巣は認められず，同年 5 月 16 日当科外来を紹介 され受診し，切除目的にて 5 月 20 日入院した。 
入院時現症 : 左腋窩部に $7.5 \times 6 \times 1.5 \mathrm{~cm}$ 大の 境界明瞭なドーム状に隆起した暗紫紅色腫瘤を 認めた。腫瘤は弾性硬，表面平滑で上皮と癒着 し，下床との可動性は比較的良好であった（図 1 )。

臨床検査所見：末梢血液に異常なく，血液生 化学検査では血糖值の軽度上昇 $(118 \mathrm{mg} / \mathrm{m} l)$ を認める以外，特に異常は認められなかった。 CEA, AFP, CA19-9, CA72-4, $\gamma$-セミノプロ テイン, PAP, NSE, CYFRA など各種腫瘍 マーカーも正常範囲内であった。

腹部 CT で脂肪肝を認めたが，その他，頭部

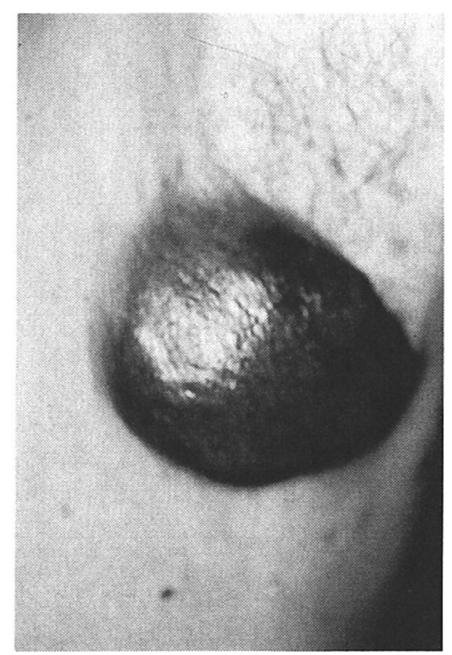

図 1. 初診時臨床像

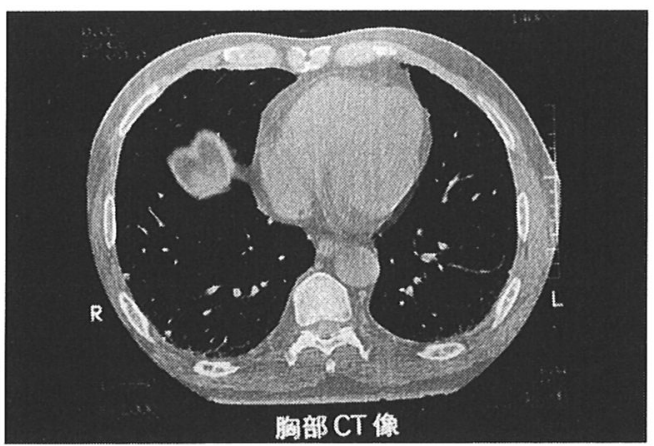

図 3，入院時胸部 CT 像 肺野末梢に微小結節影を数個認めた
CT, 骨シンチで異常は認められなかった。胸部 CT 像では，左腋窩部に境界明瞭な楕円形の腫 瘤とリンパ節の腫大を認め (図 2), 肺野末梢に は数 $\mathrm{mm}$ 大の結節影を数個認めた（図3）。この 肺野末梢の異常陰影は，前医で行った CT 像と 比較して, 大きさ, 数とも変化していなかった。

治 療：以上の所見より,アポクリン腺癌な どの皮膚原発の腫瘍と判断し, 辺縁より $3 \mathrm{~cm}$ 離 して腫瘍塊を切除し，これと一塊としたまま en bloc で左腋窩のリンパ節郭清を行った。

病理組織学的所見：病変は真皮上層から皮下 脂肪織にかけて存在し (図 4), 線維性隔壁で分

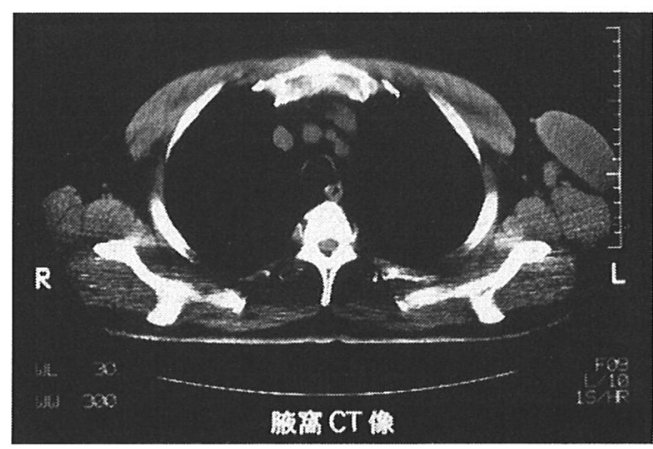

図 2，入院時腋窩 $\mathrm{CT}$ 像 左腋窩の境界明瞭な腫瘤とリンパ節の腫大

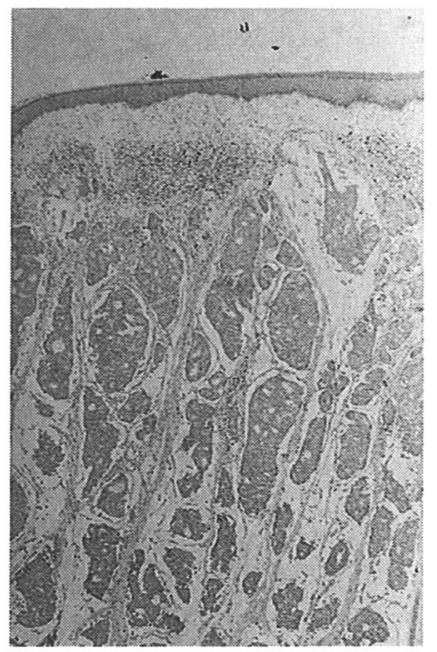

図 4.H. E. 染色弱拡大像 真皮上層から皮下脂肪織にかけての腫瘍増殖 
けられた粘液様物質中に, 充実性および腺管構 造を形成した腫瘍細胞が，浮遊しているように 存在していた（図５）。HE 染色に㧍いて腫瘍細 胞はわずかに好酸性の細胞質を示し, 核分裂像 や異型性は著明ではなかった（図 6)。

組織化学的所見 : 粘液様物質はムチカルミン 染色陽性, PAS 染色陽性でジアスターゼでは消 化されず，アルシアン・ブルー染色 $\mathrm{pH} 1.0$ で弱 陽性, pH2.5 で陽性でヒアルロニダーゼでは消 化されなかった。 mixed tumor などでみられる

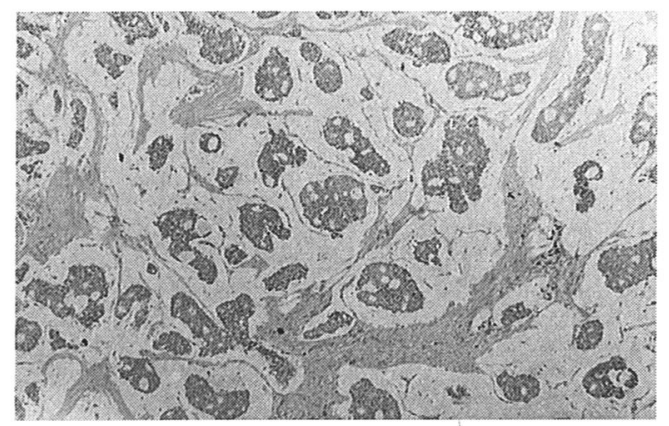

図 5. H. E. 染色弱拡大像

粘液様物質中に腫瘍細胞が浮遊するように増殖

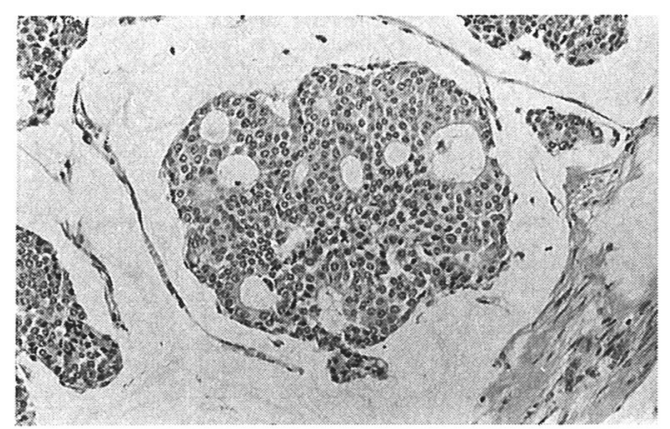

図 6. H. E. 染色強拡大像

腫瘍細胞の核分裂像や異型性は著明ではない
強酸性ムコ多糖類と異なり mucinous carcinoma of the skin でみられる粘液様物質は, 非硫酸性ムコ物質で，おそらくシアロムチンで あるとされている1”。本症例においても過去の 報告例 ${ }^{1)}$ と同様の組織化学的所見を示したため (表 1 ), mucinous carcinoma of the skin と診断 した。また，左腋窩のリンパ節にも同様の腫瘍 細胞の増殖を認め, リンパ節転移と診断した。

経 過: 手術後の経過は良好で, 約 1 力月後 の平成 9 年 7 月, 退院となった。手術後約 1 年 に行った胸部 CT 像で, 肺野末梢の結節影は, 数, 大きさともに増加, 増大傾向が認められ (図 7), 肺転移像と考えられるが, 現在のとこ ろ呼吸困難などの自覚症状は認められていな w。

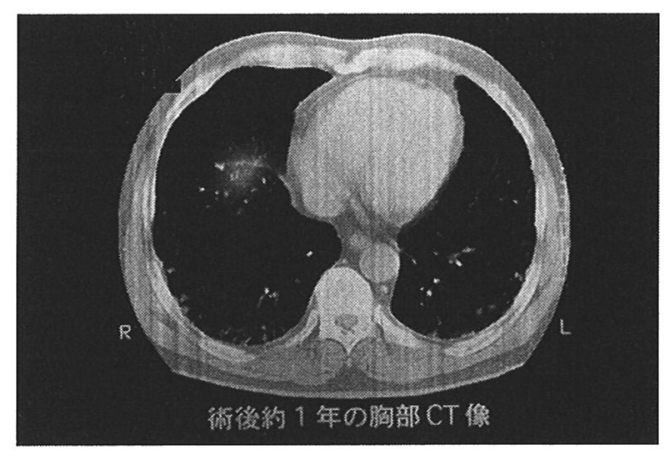

図 7.1 年後の胸部 CT 像 肺野末梢の結節影は増加増大

表 1 . 組織化学的所見

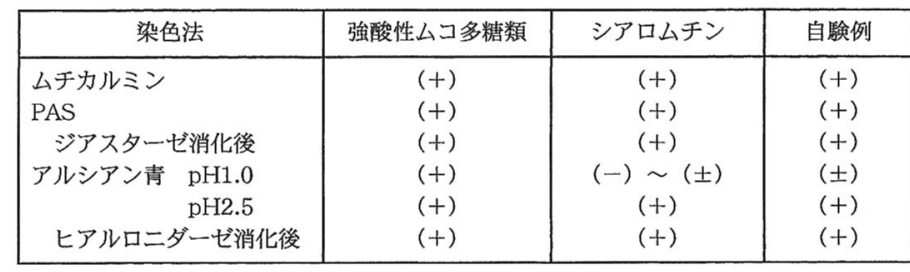

（+）強陽性、（土）司阿陽性、（一）陰性 
表 2. mucinous carcinoma of the skin の転移報告例

\begin{tabular}{|l|l|c|c|c|}
\hline 報告年 & \multicolumn{1}{|c|}{ 報告者 } & 年齢、性 & 部位 & 転移部位 \\
\hline 1954年 & Wolfe, J. J. \& Segerberg, L. H. 4) & 62女 & 頭部 & リンパ節 \\
\hline 1968年 & Berg, J. W. \& McDivitt, R. W. 5) & 70 男 & 頭部 & リンパ節 \\
\hline 1971年 & Mendoza, S. \& Helwig, E. B. 1) & 66男 & 腋窩 & リンパ節 \\
\hline 1974年 & Metz, J. et al 6) & 63男 & 頭部 & リンパ節 \\
\hline 1977年 & Yeung, K. \& Stinson, J. C. 7) & 59男 & 腋窩 & リンパ節、全身 \\
\hline 1978年 & Rao, K. V. et al 8) & 40女 & 足背 & リンパ節、全身 \\
\hline 1979年 & Wright, J. D. \& Font, R. L. 9) & 55男 & 眼瞼 & リンパ節 \\
\hline 1985年 & Wick, M.R. et al 10) & 59男 & 腋窩 & リンパ節 \\
\hline 1985年 & Pilgrim, J.P. et al 11) & 65男 & 腋窩 & リンパ節 \\
\hline 1991年 & 39宮坂宗男ら & 下顎部 & リンパ節 \\
\hline 1995年 & 櫻根幹久ら13) & 74女 & 第4指 & 肺 \\
\hline 1998年 & 自験例 & 69男 & 腋窩 & リンパ節、肺 \\
\hline
\end{tabular}

\section{考察}

mucinous carcinoma of the skin は 1952 年に Lennox ら ${ }^{2)}$ によって初めて報告され，1971 年 Mendoza \& Helwig ${ }^{1)}$ によって提唱された疾患 概念で，これまでに海外で約 80 例，本邦で約 40 例の報告がある。本疾患においては不完全な切 除による局所再発が $27 \%^{3)}$ と高いが，転移例は 少なく，我々が調べ得た限りでは海外で 9 例 ${ }^{14) ~ 11)}$, 本邦で本症例を含めて 3 例 ${ }^{12)}{ }^{13)}$ の報告 があるのみである（表 2)。これらの中には， 様々な化学療法や放射線療法を行ったにもかか わらず全身に転移した例が 1 例 ${ }^{7)}$ ，リンパ節転 移後，全身転移をきたし死亡した例が 1 例 ${ }^{8)}$ 海 外で報告されているが, 本邦で腫瘍死の報告例 はない。中には肺転移が疑われてからも, 約 6 年間まったく無症状で経過している症例 ${ }^{13)}$ も あり，転移後も発育が緩徐であることが予想さ れる。また，化学療法や放射線療法が有効で あったとする報告例はなく，原発巣の完全な摘 出が最良の方法といわれている。

本症例では当初, 内臓悪性腫瘍の皮膚転移が 疑われたが，十分な全身検索においても原発巣 と考えられる病変が認められなかったこと，肺
野の異常陰影に関しては，末梢に存在しており 原発巣とは考えにくく，転移と考えた方が妥当 であること, 腫瘍細胞の異型性や核分裂像が著 明でなく病理組織学的所見が典型的であるこ と, 各種腫瘍マーカーが陰性であったことよ $り$, mucinous carcinoma of the skin と診断 $し$ た。

治療として, 腫瘍は左腋窩の所属リンパ節も 含めて外科的に切除した。化学療法は感受性が 悪く, 効果が期待できないこと, たとえ肺転移 であっても発育が緩徐である，と予想されたこ とに加え，患者の同意が得られず行わなかっ た。術後約 1 年経過した現在, 局所再発は認め られていない。しかし, 肺野の結節影は数, 大 きさともに増悪傾向を示しており, 今後慎重に 経過観察していく必要がある。

\section{文献}

1) Mendoza, S., Helwig, E. B. : Mucinous (adenocystic) carcinoma of the skin. Arch. Dermatol., 103 : 68-78, 1971.

2) Lennox, B., Pearse, A. G. E., Richards, H. G. H. : Mucin-secreting tumors of the skin. With special reference to the so-called mixed salivary tumor of the skin and its relation to hidroadenoma. J. 
Pathol. Bact., 64 : 865-880, 1952.

3 ）南辻泰志, 加藤文博, 斎藤和哉, 他 : Mucinous carcinoma of the skin の1例. 皮膚臨床, 39:17351737, 1997.

4) Wolfe, J. J., Segerberg, L. H. : Metastasizing sweat gland carcinoma of the scalp involving transverse sinus. Am. J. Surg., 88 : 849-851, 1954.

5) Berg, J. W., McDivitt, R. W. : Pathology of sweat gland carcinoma. Pathol. Annu., 13:123-144, 1968.

6) Metz, J., Filipp, N., Metz, G. : Mucinoses carcinom der ekkrinen schweissdrusen. Z. Hautkr., 49 : 963974, 1974.

7) Yeung, K., Stinson, J. C. : Mucinous (adenocystic) carcinoma of sweat glands with widespread metastasis. Cancer, 39 : 2556-2562, 1977.

8) Rao, K. V., Tikku, I., Kapur, M. B. et al. : Invasive primary mucinous carcinoma of the skin. Int.
Surg., 63: 168-170, 1978.

9) Wright, J. D., Font, R. L. : Mucinous sweat gland adenocarcinoma of eyelid. Cancer, $44: 1757-1768$, 1979.

10) Wick, M. R., Goellner, J. R., Wolfe, J. T. et al. : Adnexal carcinomas of the skin. Cancer, 56 :11471162, 1985.

11) Pilgrim, J. P., Wolfish, P. S., Kloss, S. G., et al. : Primary mucinous carcinoma of the skin with metastases to the lymph nodes. Am. J. Dermatopathol., 7 : 461-469, 1985.

12）宮坂宗男, 谷野隆三郎, 西村正樹, 他: Mucinous carcinoma of the skin の2 例. 日本頭蓋碞顔面外会 誌, 7:60-61, 1991.

13）櫻根幹久, 松中成浩, 南好美, 他: 右第 4 指に認 めた Mucinous carcinoma. 皮膚, 37:600-605, 1995. 